\title{
ARTICLE
}

\section{Professional Ethics for Judges - Lessons Learned from the Past. Dialogue as Didactics to Develop Moral Leadership for Judges}

\author{
Special Issue on Education in (Professional) Legal Ethics, \\ Emanuel van Dongen \& Jet Tigchelaar (eds.)
}

Alex Brenninkmeijer \& Didel Bish*

Abstract

There is an intimate link between good conduct by judges and the rule of law. The quintessence of their role is that judges shape a trustworthy and fair legal system from case to case. Ethical trading is not carved in granite, and judges must determine their course on different levels. First, it concerns personal conduct and requires integrity and reliability. On the second level, the challenge is to achieve proper adjudication by conducting a fair trial in accordance with professional standards. Third, judges exercise discretion, in which normative considerations run the risk of becoming political. They should act independently as one of the players in the trias politica. A triptych of past cases illustrate moral dilemmas judges may encounter in their profession. Calibrating the ethical compass is not an abstract or academic exercise. A dialogue at the micro (internal), meso (deliberation in chambers) and macro levels (court in constitutional framework) could be incorporated in the legal reasoning as a didactic framework to make future judges aware of their ethical challenges.

Keywords: professional ethics, ethical dilemmas, judiciary, independence.

\section{Introduction}

During a discussion with senior judges on 'ethical leadership', a judge of many years' experience countered the idea of a moral leadership role for judges by saying that judges should simply apply the law (in his case it was tax law). When it comes to ethical norms and the moral leadership of judges, what are the standards that determine what is a good judge or not? What is the role of a judge, and when does a judge act ethically?

* A.F.M. Brenninkmeijer, PhD is Member of the European Court of Auditors, Luxembourg. Professor of Institutional Aspects of the Rule of Law at Utrecht University. D.A. Bish, LLM is a trainee at the European Court of Auditors, Luxembourg. 
An interesting aspect of ethical trading is that it is not carved in granite. There is always a choice, a consideration. The word 'compass' is therefore appropriate because individual judges, judges working together on course cases and performing as a constitutional branch must determine their own course to achieve these ethical standards. Calibrating the ethical compass starts by being aware of the types of dilemmas future judges may encounter and what ethical expectations they must meet. How can we raise awareness of the ethical principles that shape the professionality of judges? At first sight, it is relevant to look at the leading principles such as ethical personal conduct, the attitude of judges regarding fair trial and the way they interpret the law. The daily practice of judges is, however, not a theoretical exercise. For that reason we argue that the didactics of professional ethics for judges should be linked with cases that illustrate the dilemmas judges encounter in their work. Case law can show them how ethical norms are adapted to actual situations and social contexts.

In this article, we present three cases in three different time frames (the Persian reign of King Cambyses, World War II, and a contemporary case) that provide striking illustrations of issues related to professional ethics for judges. These cases, without pretending that we can compare them, offer material for an exploration of professional ethics for judges, which is, on the one hand, related to daily practice but, on the other hand, illustrates that the relevant ethical dilemmas are timeless. Starting with our approach to integrating professional ethics into the curriculum (Section 2), we highlight the different levels of judicial ethics (Section 3), followed by our triptych of cases (Sections $4,5,6$ ) and ending with a reflective conclusion (Section 7).

\section{Dialogue as Didactics}

The traditional legal curriculum offers a useful framework for reflection on professional ethics for judges. Studying procedural and substantive law as well as codes of conduct educates future judges, especially in legal reasoning. Professional ethics is one of the layers of legal reasoning as the reasoning should be carried out independently and impartially, applying legal rules correctly and fairly, by paying attention to underlying principles and the probable impact of the judicial decisions on the legal subject and society at large. When judges consider their professional and ethical principles during the execution of their work, the correct application thereof is automatically integrated into their legal reasoning. Legal reasoning and the application of ethical principles become one and the same thing. Thus, issues relevant to the professional ethics of judges can be easily transformed and integrated into the traditional approach to teaching and handling case law.

In our view, the didactic form for 'setting the ethical compass' for judges is dialogue (Brenninkmeijer, 2019). The three examples presented in this article will demonstrate that dialogue is needed on three levels: micro, meso and macro. The micro level concerns the internal dialogue of a judge and is the basis for the integrity of a judge, personally and professionally. On the meso level, the ideal-typical dialogue is the cooperation of three or five judges during deliberation in chambers. This type of dialogue allows judges to reach a conclusion, even if they have different 
views on facts and law. Judges seldom vote in chambers: their discussion is conclusive but mostly by consensus. Professional ethics require judges to uphold their integrity in this context as well. The third level of dialogue is the macro level, which deals with the role of a court in the constitutional framework of the separation of powers and the needed professional distance between the state powers: the legislature, the executive and the courts.

This approach of professional ethics of judges can be easily integrated in the curriculum at the university level. The education of legal reasoning as such is the best place to raise students' awareness on the need for dialogue on these three levels. Students can discuss the cases presented in an abstract manner: however, a more effective approach might be to cast them into the role of the judges concerned. Role-play may be an appropriate didactic form. In line with Mackor's explanation that in daily practice dilemmas do not present themselves as a fully written case where it is already clear what the relevant facts and moral criteria are, we believe in a multi-perspective approach when using the cases we present as study material (Mackor, 2020) - in other words, to find the different storylines from different perspectives and by applying different levels of familiarity with the facts at hand.

Finally, experienced judges should be involved in the education on professional ethics for aspiring judges (also during the more specialized training for future judges after finishing university). It is important that they highlight the ethical aspects as part of legal reasoning, thus leaving behind the incomplete picture of 'just applying the rules' as the judge in the first sentence of this contribution. This is challenging from a didactic perspective because the interest is often focused on the case itself. Those who are able to reflect on their role as judge and the ethical dilemmas they encountered in their practice can fulfil a valuable role in the classroom.

\section{Judicial Ethics - Personal Conduct, Fair Trial, Interpretation}

\subsection{Personal Conduct}

The word 'private' in private life suggests a separation from work life. Professional abilities should not necessarily be affected by a person's choices in private life. Despite specific choices in private life, judges can be highly qualified to carry out their professional work through acquired legal knowledge, analytical skills, academic excellence, efficiency in producing judgements and social abilities in communicating with colleagues. But it is not as simple as that. There is a tension between the perception of self in private life and the performance of the duties attached to the job. The personal character of the individual judge is of major importance in upholding the reputation of the judiciary and the dignity of this office. Conduct in the private sphere affects professionalism in the courtroom. Professional ethics therefore require, first and foremost, personal integrity and reliability, although other virtues may also be of relevance.

Universal ethical norms for judges are codified by different international organisations. For example, the Bangalore Principles of Judicial Conduct (2002) stipulate independence, impartiality, integrity, propriety, equality, competence and 
diligence. Ethical standards have also been institutionalised at national level in codes of conduct. However, an explicit ethical guideline in this form is not a conditio sine qua non for the good functioning of the judiciary. Judges are supposed to act according to ethical standards, written or not. It requires goodwill and the use of their moral compass in navigating the borders of private and professional life. This is in line with one of the main points of Mackor's advice to the Dutch Lawyers Association. According to her, soft law and professional ethical theories offer only limited guidance. The emphasis should be on teaching soft skills, such as sensitivity to moral issues and familiarity with and application of socio-psychological theories, to serve as tools to prevent, identify, analyse and solve integrity problems (Mackor, 2020).

It can be difficult for judges to identify when a private action affects their professional performance negatively. Judges should also closely evaluate their relations with other people. For that reason the behaviour of close relatives may also be relevant. Judges determine the fate of those before them, and any suspicion of the presence of bias can damage this process. This is delicate and judges should always reconsider their boundaries accordingly. Their and their families' freedom in private life are thus subordinated to the high standards of ethical behaviour to which they must adhere. To a certain extent a judge operates as a permanent showcase.

\subsection{Fair Trial}

The judge is the guardian of the fair trial. The right to a fair trial is enshrined in various international treaties, constitutions and other forms of national law. The judge is thus entrusted with conducting a fair trial in accordance with professional standards to foster public confidence in justice and the rule of law.

At the national level, the legislature has put legal safeguards in place for the proper functioning of independent and impartial judges and courts (covering the organisation of the judiciary and the legal position of individual judges). Various types of procedural law guarantee the right to a fair trial. For example, rules on the treatment of parties and principles of due process (including equality of arms, hearing and rebuttal, reasonable terms, openness, reason-giving, legal certainty). In evaluating the requirements for a fair hearing, the Strasbourg Court has applied the maxim that 'justice must not only be done, but also seen to be done' (Venice Commission, 2010). In line with this maxim, recent research on perceived procedural fairness and the fair process effect on the legitimacy of judgements is of growing importance (Grootelaar, 2018).

Ultimately, it is the judge who gives substance to this right and applies the corresponding principles. Giving substance implies a trade-off and cannot be reduced to simple mathematical logic. The main question before the judge is, what does it take to achieve a fair trial in this particular case? The ethical challenge is to achieve proper adjudication in different legal contexts. Professor Mackor rightly points out that this first requires expertise. Expertise is the basis for the responsibilities and sometimes far-reaching powers of professional judges (Mackor, 2020). The judge's attitude during a court session also contributes considerably to the procedural fairness experienced by the parties (Grootelaar, 2018). 


\subsection{Interpretation}

Focusing on the professional practice of judges, we will not dive into the more philosophical discourse on jurisprudence. We provide only limited observations on potential ethical issues that may arise in relation to interpretation.

Different legal systems use different legal reasoning to ensure that judicial decision-making is defensible on legal grounds (Wendel, 2007). Civil law theory basically embraces the judge as 'the mouth that pronounces the words of the law' (Lasser, 2004). From the application of the law to the facts in a syllogistic way, the conclusion would follow as a matter of deductive logic (Merryman, 1985). In common law, the doctrine of precedent obligates a lower judge to follow prior decisions. But regardless of the legal system, general rules can never fully determine their application. Judges are faced with gaps, the open texture of language, conflicts in legislation and other ambiguities. Since they do not always have a clear answer to the legal question at stake, they must exercise discretion. The existence of judicial discretion leads to legal interpretation in which space is created for normative considerations (based on, for instance, text, content and the purpose of the legislation).

As Professor Wendel clearly explains, normative considerations in exercising discretion run the risk of political views influencing the outcome. At the interpretation level, judicial ethics aim to minimise this effect (Wendel, 2007). The ethical question then becomes, to what level can a judge review a case without overstepping limits and introducing ideological preferences or political beliefs? Judges may disagree on the equitable and just outcome in hard cases: Dura lex sed lex ('the law is hard but it is the law'). A judge cannot be expected to convince others that the decision made is the only right one. Judges are merely required to reach a conclusion in good faith that they believe is the best reading of the governing law (Greenawalt, 1975).

Judicial ethics (personal conduct, fair trial, interpretation in the profession of judges) will be illustrated in three timeframes and three - as such incomparable cases.

\section{Sisamnes - Corruptibility as a Threat to Independence}

\subsection{Judgement of Cambyses}

Herodotus introduces us to the story of Sisamnes, a royal judge under the reign of Persian King Cambyses II in the 6th century BC. After accepting a bribe, Sisamnes delivers an unjust judgement. On learning of his corruptness, the king carries out a cruel punishment. He slits Sisamnes' throat and flays off all his skin. He then cuts this into leather strips to drape the chair on which the corrupt judge used to sit to deliver his verdicts. But the king's cruelty does not end there. As a final stroke, he appoints Sisamnes' son, Otanes, to succeed his father. The young judge would now hear evidence, deliberate and pass judgements on his father's skin spread over the seat. King Cambyses's brutal choice of flaying Sisamnes illustrates the perceived seriousness of the betrayal of justice and betrayal of the people. The king transformed punishment into a permanent embodiment of the fatal consequences of betraying justice. He named the man's son as his successor, 'admonishing him to 
remember what was the judgement-seat whereon he sat' (Herodotus \& Godley, 1946).

Over 2000 years later, in 1498, Bruges' aldermen, tasked with the dispensation of justice, commission painter Gerard David to depict this ancient tale. His diptych Judgement of Cambyses contains two scenes on each panel, representing the story in four scenes: the bribery, the arrest of the judge, the flaying and the installation of the son on his father's former seat (Huygebaert et al., 2018). The aldermen hang David's diptych in the town hall, which was the focus of civic pride. The building's interior had to express, inter alia, the magistrates' service to their city, conveying piety and rigorous administration (Van der Velden, 1995). The story of Sisamnes affected people's imagination similarly in medieval and renaissance times. The scene reminded local magistrates of the consequences of betrayal of trust. Serving as an exemplum iustitiae, it was a constant warning for all judges to behave properly: to uphold their duty, to carry out their profession free of corruption and external financial influence, so guaranteeing the impartiality of the judgements handed down.

Jump forward to the beginning of the 20th century to a conference at the Chinese National Judges College for judges and educators of future judges. Speaking on the independent administration of justice, a colleague projects David's picture. Commotion arises in a setting where normally only the crowns of the Chinese participants could be seen as they leaned forward and took notes. The painting reveals one of the main concerns of Chinese judges: corruption. Even before the conference, interactions with locals demonstrated the omnipresent threat of arbitrariness and corruption in the judiciary, for instance paying bribes to judges. Arbitrariness consisted of 'rule by men'. In its application, it led to arbitrary infringement of rights or life about which nothing could be done. Besides, the non-application of generally applicable rules also formed the basis of corruption. You had no rights, but you bought benefits through bribes. The transition from rule by men (according to the will of the ruler) - arbitrariness - to rule by law - the application of generally applicable legal rules - was seen as an important step. Therefore, the moment a colleague projected the image of David's diptych on the administration of justice, its symbolic meaning resounded among the participants and reinforced one of the main points of attention for Chinese judges - and, in fact, for judges in many countries.

\subsection{Justice as a Cultural Paradigm}

Practices reflecting arbitrariness and corruption are caused by the existence of offers, weak supervision and disregard by judges of ethical standards (Arif, 2020). Sisamnes' story teaches us that judges need to uphold impartiality, propriety and integrity, not to betray justice and the people that put their faith in the proper administering of justice. Corruption and arbitrariness, and the lack of safeguards for independent and impartial justice, take away all the basis for social trust in the equitable functioning of the legal order. The cruelty of Sisamnes's fate mirrors the severity of a judiciary prone to corruption.

Corruptibility as a threat to judicial independence remains a cultural aspect of many societies. There, the need still exists of a transition from rule by men (accord- 
ing to the will of the ruler) to rule by law (under application of the law). If ruled by law, individual officials can no longer exercise (corrupt) power. As such, judges would be able to change the cultural paradigm of the people who see a court as something that can be interfered with. The judge can be seen as the ultimate controller at the top of society in the fight against corruption. And so the final step would be a transformation to the rule of law safeguarded by incorruptible courts. With the introduction of an independent judiciary, there would always be controls on the exercise of power by the state. In the Chinese constitutional system as a one party-state, judges are subordinate to the rule of the Communist Party. This contrasts significantly with modern judicial systems (Ling, 2016).

\section{World War II - Bravery as a Matter of Legal Reasoning}

\subsection{Dutch Supreme Court}

After German troops invaded the Netherlands on 10 May 1940, five years of occupation began. Prior instructions from the Dutch government from 1937 stipulated that civil servants had to perform their duties for as long as possible during enemy invasion. The Aryan Declaration, designed to discharge people with Jewish ancestors from government service, was signed by all members (except its (Jewish) president) of the Supreme Court (Van der Heijden, 2001). This led to the suspension of their president, Lodewijk Visser on 23 November 1940. His replacement by a pro-German outsider a year later was the next step for the occupiers to influence the Supreme Court (Jansen \& Venema, 2011). In addition, Reich Commissioner Seyss-Inquart issued Regulation 130/1941 that lowered the upper age limit for judges from 70 to 65 . This measure created space for those well-disposed towards the occupier, drastically changing the composition of the Supreme Court (Mazel, 1984).

By the time the court passed its notorious 'Review Judgement' (toestingsarrest) in early 1942, previous personnel changes by the occupying forces had a paralysing effect on the already limited inclination and ability to protest in public. In the judgement, the Supreme Court ruled that a decision by the Secretary-General for Justice must be regarded as a legislative measure by the occupying power: as it had the character of a law within the meaning of Dutch law, it was applicable as such. It further stated that the court had no jurisdiction to assess the internal value or fairness of such a law, nor was it permissible to review it in light of a treaty such as that of which the Hague Convention on land warfare was a part (Venema, 2009). The ruling legitimised the occupier's legislation: hands off the occupation laws. With these choices, the Supreme Court became an extension of the Nazi Hitler regime. However, it should be noted that the role of the Supreme Courts (civil law, tax law and normal criminal cases) was largely untouched by Nazi influences.

Shortly after the war, a first, not very substantiated, apology by the Supreme Court followed. After that the role of the Supreme Court during World War II faded into the background, and a long, painful and oppressive silence began. It was not until 1988 that the then president of the Supreme Court, Mr Ras, broke the silence. In an interview he admits that during the war, as a law student, he had wondered, what are those people in the Hague doing? Are they still in touch with reality? On 
the initiative of the former president of the Supreme Court, Geert Corstens, an independent and thorough study by Jansen and Venema was published in 2011 that discussed the how and why concerning this dark past (Jansen \& Venema, 2011). As Corstens himself explains, he intended to do everything he could to understand what happened and why it happened, to draw wisdom and strength from these events and to prevent a repetition of the past (Corstens, 2011).

\subsection{Nuremberg and Tokyo Trials}

After World War II, as international criminal law did not provide an adequate basis for prosecuting captured German leaders, the four allied powers (United States, France, Britain and Russia) gathered in London and signed an agreement on $8 \mathrm{Au}-$ gust 1945 establishing the laws and procedures for the International Military Tribunal. Attached to the agreement is The Charter of the International Military Tribunal (1945), which defines three categories of delinquency: crimes against peace, war crimes and crimes against humanity. While these were to some extent based on the principles of customary international law, the four allied powers, in proclaiming these crimes, reverted to a process of ex post facto legislation.

The tribunal recognises the Charter as 'the exercise of the sovereign legislative power' and sentences twelve of the twenty-two Nazi defendants to death by hanging on the afternoon of 1 October 1946 (Nuremberg Trials, 1945-1946). A further seven were sentenced to imprisonment for terms ranging from ten years to life. These sentences were carried out by virtue of a law that was not yet in force during World War II and did not threaten punishment in advance for committing these specific crimes. This raises the question of violation of the principle of nulla poena sine praevia lege, according to which a penal law cannot be applied retroactively or aggravated after the crime has taken place: no penalty without a prior written penalty provision. But the tribunal was of the opinion that the rules they applied were not ex post facto because they were an expression of international law that existed at the time of the tribunal's creation.

By the time the Far East sibling of Nuremberg, the Tokyo tribunal, opened on 3 May 1946, the Nuremberg Charter and Indictment had been thoroughly scrutinised by lawyers and others (Sellars, 2010). Yet it is the will of Tokyo's majority to support Nuremberg (International Military Tribunal for the Far East, 1948). Rather than opening the door to controversy by reasoning the matters in somewhat different language, it expresses its unqualified adherence to the relevant opinions of the Nuremberg Tribunal (Pritchard, 1998). Just a few years later, the Nuremberg findings led to the UN Genocide Convention (1948), the Universal Declaration of Human Rights (1948) as well as the Geneva Convention on the Laws and Customs of War.

\subsection{Underlying Drivers: Professional and Societal Beliefs, Moral and Emotional Motives}

Professional beliefs, social expectations, moral motives and emotional drivers formed the basis for actions and omissions by the judges and courts in and after wartime. 
Before and during World War II, the trias politica doctrine dominated the attitude of the judiciary in the Netherlands. It was felt that it should not be an autonomous legal initiator (Jansen, 2005). Especially in times of political tension, the law was the safe guideline for the judge (Van den Bergh, 2000). Therefore, the Supreme Court zealously avoided getting into political waters. An important postwar 1945 publication confirmed this approach (Van den Dries, 1945). It explained that the Supreme Court was not a political body. Its function was to monitor compliance with the law in specific cases through legal proceedings. It was to refrain from interference in political matters of the executive or legislative branches, as these institutions in turn had to refrain from interference in the judiciary. In addition, as based on Catholic and Calvinist teachings, Dutch society emphasised passivity, obedience and respect (Mazel, 1984). In line with this, prudence and a certain conformism were expected from judges and regarded as virtues. Moreover, owing to the average older age, a certain reticence was not alien to the judges (Jansen, 2005).

Simple fear was also decisive. The Nazi occupier was cruel and effective in its oppression from the start. What was termed a warning was often in fact a threat (Jansen \& Venema, 2011). And with the fear of serious reprisals from the occupier, it was easier to hide from responsibility than lead by example. In a situation that amounts to life or death, cowardice and wrongful behaviour are human as well.

From a moral point of view, many who held (high) public office had the hope that continuing would prevent worse: 'if I don't do it, someone else who is worse than me will'. Researchers often describe this as the proverbial mayoral dilemma in wartime: staying on and cooperating with the occupier and thereby mitigating the consequences of the occupation policy for the population or resigning on principle or openly opposing the occupier, sending a strong signal, but with the risk of dismissal and more room for someone well-disposed towards the occupier (Jansen, 2005; Venema, 2009). This approach was confirmed by the Supreme Court after the war in 1945. In a public apology for their position during the occupation years, they explained that the ruling of the toetsingsarrest was not the result of legal reasoning but of the decision not to reject a regulation during the occupation. At its root was the fear that the Germans would have drastically intervened in the judiciary, resulting in further deterioration in legal protection for citizens. The court found that the population would be worse off if the judiciary fell fully into Nazi hands than if it only lacked the power to review regulations. The ruling was thus part of a general strategy of the lesser evil: accommodation instead of confrontation (Venema, 2009).

The reverse situation arose in the post-war trials in Nuremberg and Tokyo. Without any precedent for an international trial of war criminals, and pursuant ex post facto prosecution law, the judges sought confrontation. Weighty reasons must have influenced them. To hold accountable those who caused immeasurable suffering, they stretched the domain of international law and formulated, for the first time, the proposition that aggressive war is criminal and should be treated that way. The question arises whether, in doing so, they violated the nulla poena sine praevia lege principle. At all events, through legal interpretation they satisfied the desire to serve and strengthen peace (Leonhardt, 1949). In their own words: 'this 
law is not static, but by continual adaptation follows the needs of a changing world' (Nuremberg Trials, 1945-1946). The same idea is enshrined in Article 7, par. 2, of the European Convention on Human Rights (1950):

This article shall not prejudice the trial and punishment of any person for any act or omission which, at the time when it was committed, was criminal according to the general principles of law recognized by civilised nations.

\subsection{Judicial Interpretation and Parrhesia}

One way to elucidate the difference between law and ethics is to look at what we can now qualify as 'wrong legislation'. Judicial interpretation is a method of adapting the law to changing social circumstances. Judges are children of their time, and legal application is therefore not value free. For the concrete application of the law, judges are often required to add something new to what already exists. The decisive factor in a judicial decision is the judge's conscience. As Scholten beautifully puts it, the judge's own sense of justice is the inner justification of the decision (Scholten, 1974).

But even in the presence of an inner conviction of what is just, the adage 'speaking truth to power' (daring to contradict the mighty) is necessary to attain justice. It can involve risks, and it is often safer to shy away from explicit action, especially under the pressure of threats and intimidation. The concept of parrhesia in ancient Greek times - pan (everything) and rhema (what has been said), speaking freely what a person has in mind - is the opposite of 'keeping the peace'.

The differing attitudes of the Supreme Court and International Military Tribunal illustrate the practical consequences of applying the concept of parrhesia. Dutch judges in the Supreme Court can be accused of not having found a way to set aside the occupation law. In parallel, crimes in Nuremberg and Tokyo were made punishable on the basis of legal grounds that were not formulated until the end of World War II and thereafter (Röling, 2014). The difference in approach of these two groups of judges teaches us the virtue of courage in carrying out their duties (Van Domselaar, 2017). If fear takes over, all normative requirements take a back seat. Parrhesia is also reflected in Corstens' courage to look ahead and be open to and take responsibility for the painful lessons of the past. As he supported a valuable evaluation of the wartime role of the Dutch Supreme Court, fifty years after the fact an in-depth analysis of what happened was finally presented.

The independence of the judiciary bears the hallmark of the parrhesion contract in institutionalised form. The state should provide the offices and organisations that, with their statements, can oppose the voices of politicians or government. This includes the judiciary, which should be an independent institution free from outside pressure. In the World War II case we observe that external pressure can consist of coercion, such as what occurs in wartime, but likewise it can be caused by pressure to lead by example and reinforce the words 'never again'. Individual judges of the Tokyo tribunal were pressured to uphold the Nuremberg ruling. After critical scrutiny of this ruling, which many jurists found to fall short on legal grounds, the compulsion to defer to Nuremberg was never publicly stated. But it was clear that the Tokyo bench was split, and the Allies' officials personally 
attempted to influence the judges to make sure that the verdict echoed the Nuremberg line (Sellars, 2010). The determination of the prosecuting power jeopardised the parrhesia contract in institutionalised form (speaking freely what one has in mind) by undermining the Tokyo judges' autonomy.

\section{Child Welfare Benefits Scandal - the Judge as Guardian of the Rule of Law}

\subsection{Parliamentary Committee of Inquiry: Reconstruction of the Scandal}

At the end of 2020, a parliamentary committee of inquiry in the Netherlands issued a report with far-reaching conclusions (Parlementaire ondervragingscommissie Kinderopvangtoeslag, 2020). This led to the dismissal of the third cabinet led by the leader of the liberals, Mark Rutte. The scandal involved about 30,000 parents who were confronted with discriminatory recovery actions by the tax authority. In the report, the committee criticised not only the tax authority and the responsible ministers, but also the judicial branch of the Council of State. The Council of State is not part of the ordinary judicial system and has two branches. In addition to the judicial branch, it consists of an advisory branch. This branch scrutinises all new legislation and can advise the government on its own initiative. Under the heading 'The fundamental principles of the rule of law are violated', it was concluded that the judicial branch of the Council of State had essentially contributed to the continuation of a non-mandatory and extremely severe application of the law. For years, its case law confirmed the strict interpretation of the law that formed the basis for drastic recovery actions.

From a separation of powers perspective, it is quite unusual for parliament to criticise judicial courts. However, neither public opinion nor scholars opposed this strong criticism. What had happened for the Council of State to get into this uncomfortable position? The Dutch legislature had set up various benefit schemes to provide financial support for lower incomes. These schemes were rather generous, as benefits were paid by the administration without strict prior control. Only afterwards did the system recover unjustified payments. One of the benefit schemes covered the costs of childcare to support parents. Depending on income, a parent received a budget for childcare costs. The exact calculation of the amount due was made retroactively on the basis of cost declarations from childcare providers.

As the tax authority had quite a reputation for handling massive numbers in taxation decisions and the related automation of these processes, it was put in charge as well of implementing these types of benefit schemes. However, the flow of money in this new role was reversed: instead of collecting tax, it made massive payments to people in a weaker social position and within this social group to many people of colour.

From 2010, Dutch government policy focused on 'law and order'. It had a particular interest in preventing the abuse of social benefits. The philosophy behind this policy was the belief that fraud undermines the solidarity that underpins the social benefit schemes. Based on previous experiences in tax administration, the tax authority had already focused on automated fraud detection with self-learning algorithms. In response to a massive cut in resources, the tax authority proposed 
to the government a 'business model' based on fraud prevention. With this business model, the investment in fraud prevention (based on targeting fraud and recovering funds) would in fact become profitable.

\subsection{Anti-fraud Enforcement}

During the subsequent decade, the tax authority built an automated system of risk-based fraud identification. This system could bring to light major cases of fraud with social benefit schemes, such as the abuse in 2013 by a number of Bulgarian temporary migrants in the benefit schemes for the compensation of high rent on the housing market and healthcare insurance fees. As a result, media attention and political uproar in parliament led to significant political pressure, driving the tax authority to enforce even stricter fraud controls.

The generous childcare benefit scheme fell victim to non-bona fide childcare providers as well. The tax authority used a tactic to counter malicious childcare agencies via the parents, because they were the ones receiving the allowance. In the event of suspicion of fraud by the provider (although in many cases this suspicion was not substantiated at all), the parents were presented with the bill for possible malpractice: $100 \%$ recovery of the benefits already awarded. In addition, the tax authority opted for a group approach, which did not consider the actions of individual parents, whether or not culpable, but all parents affiliated with a (wrongly or incorrectly) identified childminder agency. Based on algorithmic identification, parents were identified as 'fraudulent'. Subsequently, they were faced with a complex burden of proof. However, due to the initial complexity of the childcare benefit scheme's application procedure, many parents had previously delegated this to the childcare provider, sharing their digital identification codes with them. As a consequence, most did not have access to the necessary administrative documentation and could not provide the necessary evidence.

In these enforcement cases, the tax authority kept to a strict application of the law. If proof of payment of, for instance, $€ 100$ was missing, the full sum of the benefits already awarded was reclaimed. In most cases, this was between $€ 10,000$ and 20,000. And the authority did not accept any delay in payment based on the distinction between 'intent/gross negligence'. This caused complex problems for many families and often resulted in a loss of employment, divorce or highly uncomfortable family relations.

If parents tried to object under the General Administrative Law Act (GALA), the tax authority would frustrate these attempts using administrative structures, for example by refusing to open their files. Legal aid was also denied by the legal aid authority based on the general assumption that anyone could deal with the tax authority without the aid of a lawyer. After unsuccessful objection procedures, parents could bring their case before the administrative chambers of the ordinary courts and appeal to the judicial division of the Council of State.

The Council of State upheld the case law that supported the more or less draconian application of the law. To cut a long story short, parents, on the whole, were completely unsuccessful in their demand to have the huge recovery decisions annulled or reduced to the sum unlawfully received (e.g. $€ 100)$ instead of the full amount (e.g. $€ 20,000)$. Only in 2019 did the Council of State make a U-turn refer- 
ring to a report of the Netherlands Scientific Council for Government Policy. This report noted the - limited - 'capability to act' of citizens and observed that citizens are not sufficiently 'self-reliant' to act according to rules and instructions (Wetenschappelijke Raad voor het Regeringsbeleid, 2017). It explained that a violation of the rules is not always based on unwillingness or fraudulent intentions. In response to the report, legal opinions discussed whether the Council of State was right in its earlier practice of strictly interpreting the law and the extent to which the proportionality principle could justify a derogation from strict legal rules (Brenninkmeijer, 2021; Damen, 2021).

\subsection{Sequel}

It is important to note that this affair was not uncovered by the courts or the Council of State's case law. Perseverance by investigative journalism and a lawyer - knocking on closed doors many times - brought the matter to the national Ombudsman and the Dutch Data Protection Authority (DPA). The DPA concluded that the manner of implementation by the tax authority was discriminatory (Autoriteit Persoonsgegevens, 2018). Many recoveries of childcare benefits by the tax authority were unlawful and, above all, discriminatory towards certain ethnic minorities. Legal protection under the GALA failed as well. Procedures were frustrated by the administration, and the Council of State failed to deliver the necessary legal protection.

In an analysis of what happened, the conclusions of the parliamentary committee of inquiry imply, first, that the legislature did not provide for an explicit 'escape-clause' in the anti-fraud legislation in order to balance the consequences of anti-fraud enforcement. Second, parliament itself failed in its duty to control the executive. The government majority in parliament and the cabinet operated in a symbiotic relationship: like a train and tender. Third, the judiciary was unable to withstand the additional pressure placed on the courts because of the weakened role of parliament. It failed as the last but most important guardian of the rule of law.

Ultimately, the committee of inquiry held up a mirror to the legislative, executive and judicial branch. The report revealed how badly the functioning of these opposing forces appears to have been affected (Brenninkmeijer, 2021). The origin of this system failure was the inadequate functioning of feedback mechanisms, the ignoring and distorting of feedback signals or an inadequate response to those signals. The three powers in the trias politica were weak in upholding the needed checks and balances, owing to the Dutch constitutional tradition in which they operate in 'close' cooperation - too close. Failure in the trias politica resulted in the misunderstanding and violation of the general principles of good governance.

The Rutte government resigned on 15 January 2021. It presented parliament with an extensive plan for improving the executive branch. In a parliamentary discussion, a motion was also adopted asking the Venice Commission of the Council of Europe to evaluate the Council of State as a judicial body. Some perceived this parliamentary motion as a humiliation of the Council of State. The Council of State responded promptly and in an extraordinary way to the damning parliamentary conclusions. Although courts usually communicate through their rulings, the pres- 
ident of the judicial branch of the Council of State gave an interview to a newspaper and presented observations in the Dutch Legal Journal. He announced a reflection on the Council's role in this scandal (Van Ettekoven, 2021).

\subsection{Reflection on the Role of the Council}

What should be on the agenda for this reflection? The reflection will concern many aspects of case law and the choices made by the Council of State during the twenty-five years of GALA's existence. However, the functioning of this part of the judiciary should be regarded in the context of the Dutch constitutional system and especially the functioning of the trias politica as a system of checks and balances.

As the Council of State has a dual role, its advisory branch, in fact, even published an advice on strengthening the legal protection of citizens a day after the publication of the critical parliamentary report (Raad van State, 2020). The advice, however, dealt on an abstract level with the relationship between the different state powers in the trias politica. It did not answer the question of how to prevent citizens from not being heard and of how to protect them against abuse of power and arbitrariness.

The lack of protection against abuse of power and arbitrariness can be partly explained by the Council's interpretation of the GALA. It not only decides cases on the presumption that a contested administrative decision is lawful, but it also applies the procedural rules in the GALA in such a way that authorities can correct their decision during the proceedings of the court in order to avoid an annulment ('final dispute resolution'). But if the court upholds the interests of the administrative body with the aim of maintaining a decision, it loses sight of the required equality of arms, especially since citizens, on the other hand, are faced with many material hurdles in bringing their case before the Council.

The case law thus revealed an ongoing problem identified by several legal scholars over the past twenty-five years: an administrative court that had become 'government friendly' but 'citizen unfriendly' (see for example Barkhuysen \& Emmerik, 2019; Damen, 2019; Jue, 2020; Mallan, 2014; Verburg, 2019; Verheij, 2005). Judges were making less and less use of the independent investigative powers that the legislature had provided for in the GALA, with disproportionate outcomes as a result (Marseille, 2020; Marseille \& Wever, 2019; Van Ettekoven, 2021). In addition, the Council applied the principle of proportionality and reviewed arbitrariness only to a very limited extent in its assessments. It did not make its own assessment based on a proper interpretation of the law.

We observe that the judiciary could have made greater use of the instruments at its disposal to arrive at just outcomes. It could also have conducted a deeper substantive review to ensure a fair trial with equality of arms. But the Council kept its distance from the way in which the tax authority implemented the benefit schemes. As an embodiment of independence in the context of the separation of state powers, it remained aloof, acting according to the motto 'the judge cannot sit on the chair of the legislat[ure]'. However, by not reviewing critically enough, the Council was in fact sucked into the administration. It created an imbalance in the relationship between the administration and the citizen instead of actively ensuring the principle of 'equality of arms' and a fair trial. 
Choosing to steer clear of becoming political in its assessments thus had a boomerang effect. The Council did not put fairness first but applied the law strictly. Rather than providing legal protection, it exercised an overly technocratic application of the law in its review of administrative decisions. This restriction undermined the value of justice. The Council did not make a legal assessment but a political-administrative one. Its position was government oriented, and the necessary impartial stance was lacking. As a consequence, it lost its independent role. It became an extension of public administration, and, as such, its decisions became political, rendering the citizen as the ultimate victim.

This behaviour begs the ethical question: what are the limits of judicial independence? What is the scope of a judge's discretion? When assessing the response to this question, the options can range from restraint to fully testing decisions based on powers laid down in law. These choices depend on context and the question: what does it take to achieve procedural fairness without going beyond the bounds of the law? The foregoing case showed a wide spectrum of additional elements that must be taken into account, such as access to justice, the balance between the position of the citizen and the government, equality of arms in the procedure (but also subjects undiscussed, such as the need for institutionalised contradiction in court proceedings, the attitude towards lower courts when it comes to bottom-up initiatives in the judicial system, interaction between the jurisdiction of the administrative court and decision-making in government administration, and the signals that the judge sends to the administration) (Brenninkmeijer \& Marseille, 2021).

\section{Reflective Conclusion}

Judges should be aware of their important role in upholding - on a case-by-case basis - the rule of law, and they must contribute to trust in society. They should lead by example, even in their private lives. They should act as 'honest men', by doing justice. To actively support a fair trial, they should interpret the law fairly. They should act independently as one of the players in the trias politica, as the cornerstone of the rule of law.

The quintessence of their role under the rule of law is that the judge shapes a trustworthy and fair legal system from case to case. For that reason, judges need to calibrate their ethical compass from time to time. In particular, their judging role is not determined exclusively by the applicable rules and procedures. Calibrating the ethical compass is not an abstract or academic exercise. For that reason, daily practice can help shape ethics for judges, for instance by dialogue. International treaties, national legislation, codes of conduct and rules of practice can support this process, but, ultimately, judges have to make their own independent choices.

Our analysis of three cases illustrates this, starting with the social and cultural impact of the corruptibility of judges (Sisamnes in $6 \mathrm{BC}$ ), the difficult choices during wartime occupation and the sentencing of wartime crimes (World War II), and, most recently, the judicial branch of the Council of State that did not protect citizens from discriminatory and arbitrary recovery actions by the administration (child welfare benefits scandal). Although these are, of course, extreme situations, 
they give an impression of what kind of norms a judge should apply and what kind of deliberations are needed and what dilemmas such situations can entail.

The Sisamnes storyline (Section 4.1) shows that the corruptibility of a judge is the greatest threat to the independence of the judiciary. Trust is fundamental to the sound functioning of the legal system. The judge, as guardian of the rule of law, must be completely trustworthy. The independence and integrity of judges is, to a large extent, not an 'incremental' issue. Judges should be 'fully' independent and of impeccable integrity. This case entails a micro level dialogue. The cruel fate of judge Sisamnes, who accepted bribes, also reflects the paramount importance of the independence of judges and courts and thus addresses the macro level dialogue for setting the ethical compass.

The role of courts during wartime occupation is a difficult one from the perspective of the ethical compass. It reflects a dialogue on the meso level as the judges collectively deliberate over which direction together with its accompanying ethical consequences is being taken. The case of the toestingsarrest from the Dutch Supreme Court illustrates the different elements of a dialogue on the interpretation of the law (Section 5.1). The same applies to the approach of the post-war judgement of the Nuremberg tribunal on the principle of nulla poena sine praevia lege (Section 5.2).

The real-life experience of an occupying power can make a major impression on judges. However, our example of the Dutch Supreme Court's case law during World War II shows that more than one storyline is possible. One storyline is that of a judge who is strongly influenced by the basic idea of separation of powers: the judge must obey the law, even if it emanates from the occupying power. The other storyline puts judges in a more courageous role: they set aside the changes that the occupying power has made in the national legal system. In doing so, judges risk falling victim to harsh repression by the occupier.

The Nuremberg and Tokyo tribunals, by contrast, offer a different storyline. Had these tribunals chosen a more legalistic approach, they could have concluded that there were no prior legal bases for sentencing war crimes committed by the German and Japanese occupiers. The fundamental nulla poena sine praevia lege principle could have prevented these tribunals from 'doing justice' on the basis of rules on crimes against peace, war crimes and, especially, crimes against humanity.

One can observe that in complex cases, or difficult cases, history may tell which choice should be considered the right one. The role of the Dutch Supreme Court and the judges was - after decades - evaluated as 'weak' and qualified as 'collaboration', 'wrong' and 'treason'. The choice made by the Nuremberg and Tokyo tribunals to condemn crimes based on, among other grounds, crimes against humanity which were not yet prescribed by law before World War II, can count on the support of many scholars and the broader public.

The role of the Council of State in the child welfare benefits scandal (Section 6.4) is so recent that we cannot base our evaluation on the lessons that time will teach. However, the step forward that the president has taken, namely to discuss the Council's role openly in a newspaper and in a prominent legal journal, shows a brave approach on the micro level - not hiding from critics but announcing a reflection on the role of the Council of State in this scandal and, possibly, the 
consequences for future case law. On the meso level we observe that the remarkable U-turn in the case law of the Council of State in the child welfare benefits case provokes a dialogue on the role of the judge in upholding the rule of law. On the macro level this case demonstrates the possible consequences of a weak framework of the separation of powers.

This article has attempted to provide future judges with insights to determine their own course when faced with moral dilemmas in their profession. Dissecting past cases teaches us that 'simply applying the law' is a far-fetched ideal and overlooks important ethical aspects of the profession. To paraphrase Carbonnier's words (quoted by Lasser, 2009), judges are human and not syllogism machines: they judge by intuition and sensitivity as much as by knowledge of [legal] rules and logic. The case studies demonstrate that judicial ethics require norms for personal conduct, professional standards in enforcing a fair trial, and an independent final assessment of a case. Ultimately, judges have to act and decide according to their beliefs of what is right. They cannot yield different storylines: one verdict is one story with one conclusion.

\section{References}

Arif, M. (2020). Violation of the professional code of ethics for judges and its consequences for judicial administration. Pancasila and Law Review, 1(2), 127-136. doi:10.25041/plr. v1i2.2128.

Autoriteit Persoonsgegevens. (2018). Belastingdienst/Toeslagen: De verwerking van de nationaliteit van aanvragers van kinderopvangtoeslag: Onderzoeksrapport (z2018-22445). Retrieved from https://autoriteitpersoonsgegevens.nl/sites/default/files/atoms/files/ onderzoek_belastingdienst_kinderopvangtoeslag.pdf (last accessed 10 March 2021).

Barkhuysen, T. \& Van Emmerik, M. (2019). Equality of arms en de Algemene wet bestuursrecht. In T. Barkhuysen, A. T. Marseille, W. den Ouden, J. A. F. Peters \& R. J. N. Schlössels (Eds.). 25 jaar Awb: In eenheid en verscheidenheid (pp. 245-251). Wolters Kluwer.

Brenninkmeijer, A. F. M. (2019). Moreel leiderschap. Prometheus Amsterdam.

Brenninkmeijer, A. F. M. (2021). 'De grondbeginselen van de staat zijn geschonden', als 'verschrikkelijk ongeluk': Over de noodzaak van behoorlijk bestuur. Nederlands Juristenblad, 1, 6-13.

Brenninkmeijer, A. F. M. \& Marseille, A. T. (2021). Een dialoog met de Raad van State na de toeslagenaffaire. Nederlands Juristenblad, 8, 575-608.

Corstens, G. (2011). Hoge Raad en de Tweede Wereldoorlog. Nederlands Juristenblad, 39, 2093-2141.

Damen, L. (2019). Van Awbmens naar responsieve burger? In T. Barkhuysen, A. T. Marseille, W. den Ouden, J. A. F. Peters \& R. J. N. Schlössels (Eds.). 25 jaar Awb: In eenheid en verscheidenheid (pp. 113-122). Wolters Kluwer.

Damen, L. (2021). Ik was het niet, ik was het niet, het was de wetgever! Nederlands Juristenblad, 5, 371-374.

European Commission for Democracy through Law, Venice Commission. (2010). Report on the Independence of the Judicial System Part I: The Independence of Judges (CDL$\mathrm{AD}(2010) 004)$. Council of Europe. Retrieved from www.venice.coe.int/webforms/ documents/?pdf=CDL-AD(2010)004-e (last accessed 10 March 2021).

Greenawalt, K. (1975). Discretion and judicial decision: The elusive quest for the fetters that bind judges. Columbia Law Review, 75(2), 359-399. doi:10.2307/1121660. 
Grootelaar, H. A. M. (2018). Interacting with procedural justice in courts (Doctoral dissertation, Utrecht University).

Herodotus, H. \& Godley, A. D. (Transl.) (1946). Herodotus: With an English translation by A.D. Godley. Heinemann.

Huygebaert, S., Martyn, G., Paumen, V., Bousmar, E. \& Rousseaux, X. (2018). The art of law: Artistic representations and iconography of law and justice in context, from the middle ages to the first world war. Springer International Publishing. doi:10.1007/978-3-319-90787-1.

International Military Tribunal for the Far East: Judgment of 4 November 1948 (1948).

Jansen, C. J. H. (2005). De spagaat van de leden van de Hoge Raad in de Tweede Wereldoorlog. Nederlands Juristenblad, 17, 880-886.

Jansen, C. J. H. \& Venema, D. (2011). De Hoge Raad en de Tweede Wereldoorlog: Recht en rechtsbeoefening in de jaren 1930-1950. Boom Uitgevers Amsterdam.

Jue, R. (2020). Maatschappelijk effectiever rechtspreken. Nederlands Juristenblad, 3, 181229.

Lasser, M. S.-O.-L. E. (2009). Judicial deliberations: A comparative analysis of judicial transparency and legitimacy. Oxford University Press. doi:10.1093/acprof:oso/9780199575169.001.0001.

Leonhardt, H. (1949). The Nuremberg trial: A legal analysis. The Review of Politics, 11(4), 449-476.

Ling, L. (2016). The Chinese communist party and people's courts: Judicial dependence in China. The American Journal of Comparative Law, 64(1), 37-74. doi:10.5131/ AJCL.2016.0002.

Mackor, A-R. (2020). Juridische beroepsethiek: Over macht en moraal, soft law en soft skills, T-vormige juristen en kansen-rechters. In A. Berlee, M. A. P. Bovens, J. Silvis \& T. F. E. Tjong Tjin Tai (Eds.). De toekomst van de jurist, de jurist van de toekomst (pp. 75107). Wolters Kluwer.

Mallan, A. (2014). Lekenbescherming in het bestuursprocesrecht (Doctoral dissertation, Tilburg University). Wolf Legal Publishers.

Marseille, A. T. (2020). Kinderopvangtoeslagen: wel of geen beleidsvrijheid voor de Belastingdienst/Toeslagen? Ars Aequi, 4, 393-399.

Marseille, A. T. \& Wever, M. (2019). Snelheid, maatwerk en finaliteit in bestuursrechtelijke procedures bij de rechtbank. Nederlands Juristenblad, 41, 3080-3090.

Mazel, P. E. (1984). In naam van het recht...: de Hoge Raad en de Tweede Wereldoorlog. Gouda Quint.

Merryman, J. H. (1985). The civil law tradition: An introduction to the legal systems of Europe and Latin America (2nd ed.). Stanford University Press.

Parlementaire ondervragingscommissie Kinderopvangtoeslag. (2020). Ongekend onrecht. Tweede Kamer der Staten-Generaal. Retrieved from www.tweedekamer.nl/sites/ default/files/atoms/files/20201217_eindverslag_ parlementaire_ondervragingscommissie_kinderopvangtoeslag.pdf (last accessed 10 March 2021).

Pritchard, R. J. (1998). The judgment of the tribunal; Pt. 1. (Transcript pages 48413-48880): Thursday, 4th November - Friday, 5th November 1948. Lewiston.

Raad van State. (2020). Verzoek om voorlichting naar aanleiding van de motie-Backer c.s. over versterking van de kwaliteit van de rechtsbescherming voor de individuele burger (W16.20.0242/II/Vo). Retrieved from www.raadvanstate.nl/adviezen/@121764/w1620- 0242-ii-vo/\#highlight=rechtsstaat (last accessed 10 March 2021).

Röling, H. (2014). De rechter die geen ontzag had: Bert Röling en het Tokiotribunaal. Wereldbibliotheek.

Scholten, P. (1974). Asser Serie: Algemeen deel (3rd ed.). W. E. Tjeenk Willink. Wolters Kluwer.

Sellars, K. (2011). Imperfect justice at Nuremberg and Tokyo. European Journal of International Law, 21(4), 1085-1102. doi:10.1093/ejil/chq070. 
Trial of the Major War Criminals before the International Military Tribunal: Nuremberg 14 November 1945 - 1 October 1946 (Vol. I).

United Nations Charter of the International Military Tribunal: Annex to the agreement for the prosecution and punishment of the major war criminals of the European Axis, $8 \mathrm{Au}-$ gust 1945. Retrieved from www.refworld.org/docid/3ae6b39614.html (last accessed 10 March 2021).

Van den Bergh, G. C. J. J. (2000). Geleerd recht: Een geschiedenis van de Europese rechtswetenschap in vogelvlucht (4th ed.). Kluwer.

Van den Dries, N. C. M. A. (1945), De Hooge Raad der Nederlanden tijdens de bezetting. E. J. Brill.

Van der Heijden, C. (2001). Grijs verleden: Nederland en de Tweede Wereldoorlog (1st ed.). Amsterdam/Antwerpen.

Van der Velden, H. (1995). Cambyses for example: The origins and function of an exemplum iustitiae in Netherlandish art of the fifteenth, sixteenth and seventeenth centuries. Simiolus: Netherlands Quarterly for the History of Art, 23(1), 5-62. doi:10.2307/3780781.

Van Domselaar, I. (2017). Moedige juristen in alledaagse context: onbekend en onbemind? Weekblad voor Privaatrecht, Notariaat en Registratie, 7175, 1005-1010.

Van Ettekoven, B. J. (2021). Tussen wet en recht: Reactie van de voorzitter van de Afdeling bestuursrechtspraak van de Raad van State op het rapport Ongekend onrecht van de Parlementaire ondervragingscommissie Kinderopvangtoeslag. Nederlands Juristenblad, 2, 98-107.

Verheij, N. (2005). Relatief onaantastbaar? Over formele rechtskracht van besluiten (Dissertation, Universiteit Maastricht). doi:10.26481/spe.20050121nv.

Venema, D. (2009). Het Toetsingsarrest. Ars Aequi, 58(12), 846-849.

Verburg, D. A. (2019). Bestuursrechtspraak in balans: Bejegening, beslechting en bewijs (Doctoral dissertation, Utrecht University). Boom juridisch.

Wendel, W. B. (2007). Jurisprudence and judicial ethics. Cornell Law Faculty Publications.

Wetenschappelijke Raad voor het Regeringsbeleid. (2017). Weten is nog geen doen. Een realistisch perspectief op redzaamheid. Retrieved from www.wrr.nl/publicaties/ rapporten/2017/04/24/weten-is-nog-geen-doen\#: :text=Met\%20dit\%20rapport\%20 zet\%20de,op\%20de\%20niet\%2Dcognitieve\%20vermogens (last accessed 10 March 2021). 